\title{
Prevalence of Anal Incontinence and Constipation in Female Patients with Urinary Incontinence
}

\section{Üriner İnkontinansı Kadın Hastalarda Anal İnkontinans ve Konstipasyon Görülme Sıklığı}

\author{
Musa Saraçoğlu', Aşkın Eroğlu², Rauf Taner Divrik ${ }^{3}$ \\ 'Deniz Hospital, Clinic of Urology, İmir, Turkiye \\ ${ }^{2}$ Başkent University Faculty of Medicine, Department of Urology, Izmir, Turkiye \\ ${ }^{3}$ Ege City Hospital, Clinic of Urology, izmir, Turkiye
}

\begin{abstract}
What's known on the subject? and What does the study add?
Urinary incontinence and anal incontinence are quite prevalent conditions. On the other hand, some studies have been performed to investigate both of these entities with the hypothesis that they could co-exist due to common risk factors playing a role in the etiopathogenesis. Nevertheless, most of these studies involved elderly and home-care patients. This study aims at investigating the incidence of anal incontinence and constipation in patients with urinary incontinence in all adult age groups.
\end{abstract}

\begin{abstract}
Objective: To investigate the prevalence of anal incontinence and constipation in patients with urinary incontinence.

Materials and Methods: Adult female patients who presented with the complaint of urinary incontinence were evaluated with anal incontinence and constipation assessment survey prepared on the basis of "the International Consultation on Incontinence Questionnaire-Short Form", "the Overactive Bladder 8-Question Awareness Tool" and "the Rome 3" criteria.

Results: Two hundred female patients with urinary incontinence were evaluated. The patients were in the age group of 18-88 with the average age of $55.24 \pm 16.86$ standard deviation. Stress incontinence was present in 19.5\%, urge incontinence in $36 \%$ and mixed incontinence in $44.5 \%$ of the subjects. Seventy-seven percent of patients presented with flatal incontinence, $7.5 \%$ with fecal incontinence and $52.5 \%$ presented with constipation. There was no difference between sub-groups created according to age groups and types of urinary incontinence in terms of frequency of gastrointestinal symptoms. The incidence of constipation was statistically significantly higher in patients presenting with findings of urinary incontinence for more than 1 year and in those with overactive bladder ( $p<0.01$ and $p<0.001$, respectively).

Conclusion: Flatal incontinence was found in 77\%, fecal incontinence in 7.5\% and constipation in 52.2\% of female adult patients with urinary incontinence. The incidence of constipation was higher at the level of statistical significance in patients presenting with findings of urinary incontinence for more than 1 year and in those with overactive bladder.
\end{abstract}

Keywords: Urinary incontinence, Overactive bladder, Anal incontinence, Fecal incontinence, Constipation

$\ddot{0 z z}$

Amaç: Bu çalışmanın amacı üriner inkontinansı hastalarda anal inkontinans ve konstipasyon görülme sıkığının araştııılmasııır.

Gereç ve Yöntem: Üriner inkontinans yakınması ile başvuran erişkin kadın hastalar; "International Consultation on Incontinence Short Form", "Overactive Bladder 8-Question Awareness Tool" ve "Roma 3" kriterlerine göre hazırlanan anal inkontinans ve konstipasyon değerlendirme anket formları ile değerlendirildiler.

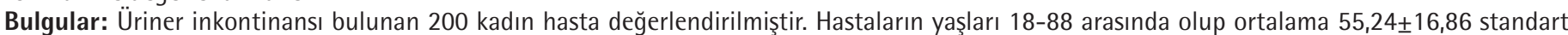
sapma olarak bulunmuştur. Stres tipi idrar kaçırma \%19,5, sıkışma tipi idrar kaçırma \%36 ve karışık tipte idrar kaçırma \%44,5 oranlarında bulunmuştur. Gaz inkontinansı \%77, fekal inkontinans \%7,5 ve konstipasyon \%52,5 oranlarında saptanmıştır. Yaş gruplarına göre ve üriner inkontinansın tiplerine göre oluşturulan alt gruplar arasında gastrointestinal semptomların görülme sıklığı açısından fark saptanmamıştır. Üriner inkontinansı bir yıldan daha uzun süreli olan hastalarda ve aşırı aktif mesanesi bulunan hastalarda konstipasyon görülme oranı istatistiksel olarak anlamlı bir şekilde daha yüksek bulunmuştur (sırasıyla; $p<0,01$ ve $p<0,001$ ).

Correspondence: Aşkın Eroğlu MD, Başkent University Faculty of Medicine, Department of Urology, İzmir, Turkiye

Phone: +90 2322411032 E-mail: askineroglu@gmail.com ORCID-ID: orcid.org//0000-0003-2404-6209

Received: 22.10 .2017

Accepted: 28.11.2017

Cite this article as: Saraçoğlu M, Eroğlu A, Divrik RT. Prevalence of Anal Incontinence and Constipation in Female Patients with Urinary Incontinence. J Urol Surg 2018;5(1):21-24.

๑Copyright 2018 by the Association of Urological Surgery / Journal of Urological Surgery published by Galenos Publishing House. 
Sonuç: Üriner inkontinansı bulunan erişkin kadınlarda gaz inkontinansı \%77, fekal inkontinans \%7,5 ve konstipasyon \%52,2 oranında görülmektedir. Konstipasyon; üriner inkontinansı bir yıldan daha uzun süreden beri bulunan hastalarda ve aşırı aktif mesanesi bulunan hastalarda istatistiksel olarak anlamlı bir şekilde daha yüksek oranlarda görülmektedir.

Anahtar Kelimeler: Üriner inkontinans, Aşırı aktif mesane, Anal inkontinans, Fekal inkontinans, Konstipasyon

\section{Introduction}

Urinary incontinence and anal incontinence are quite prevalent conditions. Many community-based studies have been performed to investigate the prevalence of these two conditions. Majority of studies have focused on urinary and anal incontinence as two distinct entities. On the other hand, some other studies have been performed to investigate both of these entities with the hypothesis that they could co-exist due to common risk factors playing a role in the etiopathogenesis $(1,2,3)$. Nevertheless, most of these studies involved elderly and home-care patients.

The later studies concentrated on the prevalence of urinary incontinence in patients with anal incontinence and vice versa. There are only a few studies on this topic and more studies are needed with a larger age span.

This study aims at investigating the prevalence of anal incontinence and constipation in patients with urinary incontinence in all adult age groups.

\section{Materials and Methods}

Female patients aged 18 years and over presenting with urinary incontinence and agreeing to fill in the questionnaires on anal incontinence and constipation at the time of routine workup were included in the study. Those who provided written informed consent were included in the study.

Patients with a history of lower urinary tract or anorectal surgery, pregnant women and those less than 6 months postpartum less than six months after labor and/or presenting with acute lower urinary tract infections were excluded.

The validated Turkish version of the International Consultation on Incontinence Questionnaire-Short Form (ICIQ-SF) and the Overactive Bladder 8-Question Awareness Tool (OAB-V8) were used to assess the lower urinary system complaints of the patients $(4,5)$.

The first two forms questioning gastrointestinal system functions are the forms prepared according to the Rome 3 diagnostic criteria. The first form questions anal incontinence. Anal incontinence was considered in two sub-types as flatal incontinence and fecal incontinence. The second form, on the other hand, questions constipation. Comorbidities were also questioned and registered. The comorbidity status was assessed according to the Charlson comorbidity index (6). The patients filled the questionnaires were filled with the supervision of a trained nurse during face-to-face interviews. The study was limited with 200 patients. The study was conducted after approval of the Ethics Board of Şifa University dated 30.01.2014 and numbered B.30.2.ŞFÜ.00.50.500/06.

\section{Statistical Analysis}

Chi-square and Fisher's exact tests were used as statistical methods to evaluate the significance of differences between two groups.

Correlation analysis was performed to evaluate the relationship between urinary incontinence and $O A B$ in comorbid cases.

\section{Results}

The study was performed between February 2014 and May 2015 , and was terminated as soon as the number of patients reached 200 .

Of the 200 patients presented with the complaint of urinary incontinence, $39(19.5 \%)$ had findings of stress incontinence, $72(36 \%)$ had urge incontinence and $89(44.5 \%)$ had mixed incontinence. The mean age of the patients was $55.24 \pm 16.86$ years ranging from 18 to 88 years. As for the age distribution according to type of urinary incontinence, stress incontinence was present in the mean age group of $50.26 \pm 14.89$, urge incontinence in $54.0 \pm 18.06$ and mixed incontinence in $58.44 \pm 16.27$.

One hundred fifty-four (77\%) patients presented with flatal incontinence, $15(7.5 \%)$ with fecal incontinence and 105 $(52.5 \%)$ with constipation. Table 1 shows the rates of flatal incontinence, fecal incontinence and constipation according to

Table 1. Incidence of gastrointestinal symptoms according to types of incontinence

\begin{tabular}{lllll}
\hline & $\mathbf{n ~ ( \% )}$ & Flatal incontinence $\mathbf{n ~ ( \% )}$ & Fecal incontinence $\mathbf{n}(\%)$ & Constipation $\mathbf{n}(\%)$ \\
\hline Stress incontinence & $39(19.5 \%)$ & $31(15.5 \%)$ & $3(1.5 \%)$ & $17(8.5 \%)$ \\
Urge incontinence & $72(36 \%)$ & $51(25.5 \%)$ & $8(4 \%)$ & $35(17.5 \%)$ \\
Mixed incontinence & $89(44.5 \%)$ & $72(36 \%)$ & $4(2 \%)$ & $53(26.5 \%)$ \\
Total & $200(100 \%)$ & $154(77 \%)$ & $15(7.5 \%)$ & $105(52.5 \%)$ \\
\hline
\end{tabular}


Table 2. Number of patients with urinary and gastrointestinal symptoms according to age groups

\begin{tabular}{|c|c|c|c|c|c|c|c|}
\hline & $\mathbf{n}$ & $\begin{array}{l}\text { SUI } \\
\text { n (\%) }\end{array}$ & $\begin{array}{l}\text { UUI } \\
\text { n (\%) }\end{array}$ & $\begin{array}{l}\text { MUI } \\
\text { n (\%) }\end{array}$ & $\begin{array}{l}\text { Ftl } \\
\text { n (\%) }\end{array}$ & $\begin{array}{l}\mathrm{FI} \\
\mathrm{n}(\%)\end{array}$ & $\begin{array}{l}\text { Constipation } \\
\text { n (\%) }\end{array}$ \\
\hline$\leq 40$ & 37 & 7 (18.9\%) & 17 (45.9\%) & $13(35.2 \%)$ & $28(75.7 \%)$ & $2(5.4 \%)$ & $18(48.7 \%)$ \\
\hline $41-50$ & 43 & $12(28 \%)$ & $11(25.6 \%)$ & $20(46.5 \%)$ & $32(74.4 \%)$ & $3(7 \%)$ & $22(51 \%)$ \\
\hline $51-60$ & 36 & $12(33.3 \%)$ & $11(30.5 \%)$ & $13(36 \%)$ & $28(77.7 \%)$ & $4(11 \%)$ & $16(44.4 \%)$ \\
\hline $61-70$ & 48 & $5(10.4 \%)$ & $24(50 \%)$ & $19(39.6 \%)$ & $36(75 \%)$ & $4(8.3 \%)$ & $24(50 \%)$ \\
\hline$\geq 71$ & 36 & $3(8.3 \%)$ & $9(25 \%)$ & $24(66.6 \%)$ & 30 (83.3\%) & $2(5.5 \%)$ & $25(69.4 \%)$ \\
\hline Total & 200 & 39 (19.5\%) & 72 (36\%) & 89 (44.5\%) & $154(77 \%)$ & 15 (7.5\%) & 105 (52.5\%) \\
\hline
\end{tabular}

SUI: Stress urinary incontinence, UUI: Urge urinary incontinence, MUI: Mixed urinary incontinence, FtI: Flatal incontinence, Fl: Fecal incontinence

types of urinary incontinence. There was no difference in the incidence of constipation between urinary incontinence and anal incontinence. $P$ value was 0.29 for flatal incontinence, 0.28 for fecal incontinence and 0.18 for constipation.

Table 2 shows the number of patients with urinary incontinence and lower gastrointestinal tract dysfunction according to the age groups. There was no statistically significant difference between age groups in terms of the prevalence of flatal incontinence, fecal incontinence and constipation $(p=0.81, p=0.88$ and $p=0.24$, respectively).

Table 3 presents an association between the duration of urinary incontinence complaints and lower gastrointestinal dysfunction. Patients having incontinence complaints for more than one year were found to have higher rates of constipation at the level of statistical significance.

One of the most prevalent diseases of the lower urinary system is $O A B$, which may be quite common in patients with urinary incontinence. $O A B$ is diagnosed with thorough evaluation of patient complaints using $O A B-V 8$. The treshold value was found to be 11 during the validation study of the Turkish version of $O A B-V 8$. Accordingly, 174 patients were found to have $O A B$ (Table 4). There was no difference in anal and fecal incontinence between patients with and without $O A B(p=0.99$ and $p=0.42$, respectively), whereas the incidence of constipation was statistically significantly higher in OAB patients $(p=0.001)$.

As for grouping of incontinent patients according to parity, there was no statistically significant difference among nulliparous, uniparous, secundiparous, triparous or other multiparous women in terms of flatal incontinence, fecal incontinence and constipation.

The patients were assessed for comorbidities using Charlson comorbidity index. The age of the patients was also considered in calculation. Nighty-three patients with a comorbidity score of 0 had no comorbidity. Fourty-seven patients with a comorbidity score of 1-3 had mild comorbidities. Sixty with a comorbidity score of 4 or higher had a moderate level of comorbidities. It was observed that Charlson comorbidity scores were weakly but
Table 3. Incidence of gastrointestinal symptoms according to duration of urinary incontinence

\begin{tabular}{lllll}
\hline & $\mathbf{N}$ & $\begin{array}{l}\text { Flatal } \\
\text { incontinence }\end{array}$ & $\begin{array}{l}\text { Fecal } \\
\text { incontinence }\end{array}$ & Constipation \\
\hline$<1$ year & 57 & 46 & 4 & 22 \\
$>1$ year & 143 & 108 & 11 & 83 \\
$\mathrm{p}$ & & 0.43 & 0.87 & 0.01 \\
\hline
\end{tabular}

Table 4. Gastrointestinal symptoms in individuals with and without overactive bladder

\begin{tabular}{lllll}
\hline & $\mathbf{n}$ & $\begin{array}{l}\text { Flatal } \\
\text { incontinence }\end{array}$ & $\begin{array}{l}\text { Fecal } \\
\text { incontinence }\end{array}$ & Constipation \\
\hline $\mathrm{OAB}+$ & 174 & 134 & 12 & 99 \\
$\mathrm{OAB}-$ & 26 & 20 & 3 & 6 \\
$\mathrm{p}$ & & 0.99 & 0.42 & 0.001 \\
\hline OAB: Overactive bladder & & \\
\hline
\end{tabular}

positively correlated with ICIQ-SF and OAB-V8 scores $(r=0.0285$ and $r=0.0147$, respectively).

Patients without comorbidities, low-risk patients and moderaterisk patients were compared in terms of anal incontinence and constipation but there was no statistically significant difference between the groups.

\section{Discussion}

Studies investigating the prevalence of urinary incontinence in women have reported a broad range of variation, from 5\% to $69 \%$. Nevertheless, most of the studies have reported a prevalence of $25-45 \%$ (7). Studies on anal incontinence have reported a prevalence of $11-15 \%$ in adults (7). Prevalence studies on anal incontinence, though, report results of $11-15 \%$ in adults (7).

The broad range of prevalence for urinary incontinence is due to lack of homogeneity in the patient population of studies and the difference in definition criteria used for incontinence. Whether or not flatal incontinence is included in anal incontinence inquiry also significantly affects the study results. 
There are some common risk factors in the etiopathogenesis of both urinary and anal incontinence including age, gender, obesity, diabetes mellitus, pelvic organ prolapse, constipation, pregnancy, parity, pelvic surgery and gynecologic surgery. Therefore, several studies have been performed to investigate the prevalence of coexistence of both conditions.

In a study done with 778 male and 762 female subjects aged 50 and older, Roberts et al. (2) reported a female urinary incontinence rate of $48.4 \%$, fecal incontinence rate of $15.2 \%$ and combined incontinence of 9.4\%. In their study including 864 elderly women, Yuaso et al. (8) reported that the incidence of combined incontinence was $4.9 \%$. In a study by Biswas et al. (9) including 177 women, it was found that $27.7 \%$ of women had urinary incontinence $28.8 \%$ had constipation and $17.5 \%$ had fecal incontinence.

Of those presenting with urinary incontinence, $41.2 \%$ also had constipation and $35.5 \%$ had fecal incontinence (9).

This study evaluated 200 women with urinary incontinence. $19.5 \%$ of patients were found to have stress incontinence, 36\%- urge incontinence and 44.5\%- mixed incontinence. This distribution corroborates with the literature. In our study, the incidence of flatal incontinence was $77 \%$, fecal incontinence was $7.5 \%$ and the incidence of constipation was $52.5 \%$. The rate of fecal incontinence was slightly lower than in the literature and slightly higher than the constipation rate, which may be due to differences in the patient population.

There was no difference between sub-groups based on age or types of urinary incontinence in terms of prevalence of gastrointestinal symptoms. Patients with urinary incontinence for one year and longer and those with $O A B$ had a statistically significantly higher prevalence of constipation $(p<0.01$ and $p<0.001$, respectively).

High rates of constipation in patients with urinary incontinence lasting more than a year could be associated with the side effects of medicines used for the treatment of incontinence and it could be associated with the impacts of pathology that led to incontinence on the gastrointestinal tract in the course of time. There is a need for further studies on this subject.

High rates of constipation in $\mathrm{OAB}$ patients could also be related with the side effects of medicines used in the treatment. At this point, there may be a common etiopathogenesis. In addition, constipation may trigger $\mathrm{OAB}$. Further studies are needed.

\section{Study Limitations}

The study included women aged 18 years and over, only using questionnaire forms, lack of pediatric patient group and male patient group, lack of functional evaluation studies for urinary system and gastrointestinal system is the missing side of the study.

\section{Conclusion}

Anal incontinence and constipation rates are critical in patients with urinary incontinence. Therefore, to question patients with urinary incontinence for other gastrointestinal symptoms, including anal incontinence and constipation, may be of key importance.

\section{Ethics}

Ethics Committee Approval: The study was conducted after approval of the Ethics Board of Şifa University dated 30.01.2014 and numbered B.30.2.ŞFÜ.00.50.500/06.

Informed Consent: It was taken.

Peer-review: Externally peer-reviewed.

\section{Authorship Contributions}

Concept: M.S., R.T.D., Design: R.T.D., A.E., Data Collection or Processing: M.S., Analysis or Interpretation: R.T.D., A.E., Literature Search: M.S., A.E., Writing: R.T.D., A.E.

Conflict of Interest: No conflict of interest was declared by the authors.

Financial Disclosure: The authors declared that this study received no financial support.

\section{References}

1. Nakanishi N, Tatara K, Nakajima K, Takabayashi H, Takahashi S, Naramura $\mathrm{H}$, Ikeda $\mathrm{K}$. Urinary and fecal incontinence in a community-residing elderly population: prevalence, correlates and prognosis. Nihon Koshu Eisei Zasshi 1997;44:192-200.

2. Roberts RO, Jacobsen SJ, Reilly WT, Pemberton JH, Lieber MM, Talley NJ. Prevalence of combined fecal and urinary incontinence: a communitybased study. J Am Geriatr Soc 1999;47:837-841.

3. Tpokinova E, Neuwirth J, Stankova M, Mellanova A, Haas T. Urinary and fecal incontinencein geriatric facilities in the Czech Republic. Cas Lek Cesk 1997;136:573-577.

4. 4.Çetinel B, Özkan B, Can G. ICIO-SF Türkçe versiyonu validasyon (geçerlilik) çalışması. Türk Üroloji Dergisi 2004;30:332-338.

5. Tarcan T, Mangır N, Özgür MÖ, Akbal C. OAB-V8 Aşırı Aktif Mesane Sorgulama Formu Validasyon Çalışması. Üroloji Bülteni 21, 2012;113-116

6. Hall $W H$, Ramachandran $R$, Narayan $S$, Jani $A B$, Vijayakumar $S$. Anelectronicapplicationforrapidly calculating Charlson comorbidity score. BMC Cancer 2004:4:94.

7. Milsom I, Altman D, De Cartwright S, Kanai AJ, et al. Epidemiologyof Urinary Incontinence andother Lower Urinary Tract Symtoms, Pelvic Organ Prolapseand Anal Incontinence. Incontinence 5th ed. In: Abrams P, Cardazo L, Khoury S, Wein A. Paris 2013, pp 72-84.

8. Yuaso DR, Santos JLF, Castro RA, Duarte YA0, Girão MJBC, Berghmans B Tamanini JTN. Female double incontinence: prevalence, incidence, and risk factors from the SABE(Health,Wellbeingand Aging) study. Int Urogynecol J 2018;29:265-272.

9. Biswas B, Bhattacharyya A, Dasgupta A, Karmakar A, Mallick N, Sembiah S. Urinary Incontinence, Its Risk Factors, and Quality of Life: A Study among Women Aged 50 Years and above in a Rural Health Facility of West Bengal. J Midlife Health 2017;8:130-136. 